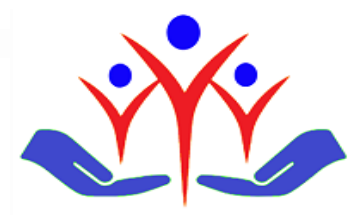

ISSN 2458-8865

\title{
Changes in systemic inflammatory and nasal mucociliary response following smoking cessation
}

Sigara bırakma sonrası sistemik inflamatuar ve nazal mukosilier yanıttaki değişiklikler

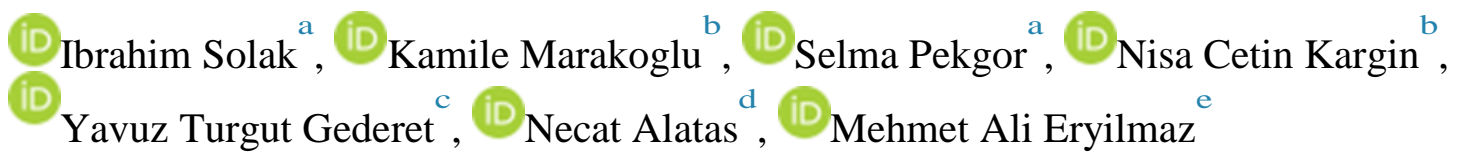

${ }^{\mathrm{a}}$ University of Health Sciences, Training and Research Hospital, Department of Family Medicine, Konya, Turkey

b Selcuk University, School of Medicine, Department of Family Medicine, Konya, Turkey

${ }^{\mathrm{c}}$ University of Health Sciences, Training and Research Hospital, Department of Biochemistry, Konya, Turkey

d University of Health Sciences, Training and Research Hospital, Department of Otorhinolaryngology, Konya, Turkey

${ }^{\mathrm{e}}$ University of Health Sciences, Training and Research Hospital, Department of General Surgery, Konya, Turkey

\begin{abstract}
Introduction: This study aimed to evaluate the changes both in the systemic inflammation and in the mucociliary clearance following smoking cessation, and their associations with smoking characteristics.

Methods: A total of 30 cases admitted to Konya Training and Research Hospital, University of Health Sciences, Department of Smoking Cessation were recruited, and 27 of them completed the study. Tumor necrosis factor alpha (TNF- $\alpha$ ), interleukin (IL) -4, IL-6, IL-8, IL-10 and saccharin transit time (STT) was measuredat the beginning and 2 months after smoking cessation.

Results: We found in this study that STT decreased significantly in 2 months after cessation ( $<<0.001)$. In our study, we found that serum TNF- $\alpha$ $(\mathrm{p}=0.035)$ and IL-8 $(\mathrm{p}=0.002)$ levels were decreased significantly at 2 months after quitting when compared with the basal levels. In our study, serum IL-6 ( $\mathrm{p}=0.132)$ and IL-10 ( $\mathrm{p}=0.657$ ) levels did not change significantly in the 2nd month of quitting, when compared to basal levels.

Conclusion: In this study, two months after smoking cessation, nasal mucosal clearance and systemic inflammatory response especially plasma TNF- $\alpha$ and IL-8 levels were improved. We think that further studies with larger sample size and longer follow-up will provide more detailed data about the improvements in systemic inflammation.
\end{abstract}

Keywords: Systemic inflammation, cytokines, saccharin transit time, smoking cessation

ÖZ

Giriș: Bu çalışmada, sigara bırakma sonrası, hem sistemik inflamasyonda hem de nasal mukosilier klirensde meydana gelen değişiklikleri ve bunların sigara içme özellikleri ile ilişkilerinin değerlendirilmesi amaçlanmıştır.

Yöntem: Sağlık Bilimleri Üniversitesi Konya Eğitim Araştırma Hastanesi Sigara Bırakma Polikliniğine başvuran 30 vaka çalışmaya dahil edilip 27 vaka ile çalışma tamamlanmıştır. Tümör nekrozis faktör-alfa (TNF- $\alpha$ ), interlökin (IL) -4, IL-6, IL-8, IL-10 ve sakarin geçiş süresi (STT), kayıt ve sigara bırakılmasından 2 ay sonra ölçüldü.

Bulgular: Bu çalışmada, STT’nin sigara bırakıldıktan 2 ay sonra anlamlı olarak kısaldığı görüldü $(p<0,001)$. Serum TNF- $\alpha(p=0,035)$ ve IL-8 $(p=0,002)$ düzeylerinin, bazal seviyelerle karşılaştırıldığında, sigara bıraktıktan sonraki 2. ayda anlamlı olarak azaldığını bulduk. Bazal seviyelerle karşılaştıııldığında, sigara bıraktıktan sonraki 2. ayda serum IL-6 (p=0,132) ve IL-10 (p=0,657) seviyelerinin değişiminin anlamlı olmadığı gözlendi.

Sonuç: Sigara bırakma işleminden iki ay sonra, nazal mukosiliyer klirens ve sistemik inflamatuar yanıtta, özellikle plazma TNF- $\alpha$ ve IL-8 düzeylerinde iyileşme görülmüştür. Daha büyük katılımlı ve daha uzun süreli sigara bırakma sonrası yapılan çalışmalarla, sistemik inflamasyondaki düzelmelerin daha ayrıntılı gösterilebileceği düşünülmektedir.

Anahtar Kelimeler: Sistemik inflamasyon, sitokin, sakarin geçiş süresi, sigara bırakma 


\section{Introduction}

Negative health, social and economic consequences of tobacco use is an important global health problem. Tobacco use is a main global disease risk factor and underlying cause of many diseases, death and disability. It is estimated that tobacco use will kill more than 5 million people every year worldwide. If current trends continue, tobacco will kill more than 8 million people worldwide every year until 2030, and $80 \%$ of these premature deaths will occur in developing countries [1]. Quitting smoking has significant favorable effects like decreases in death and stroke risks, increases in pulmonary functions, enhances in quality of life, and modifications in immune response by increases in inflammatory mediators [24].

Nasal mucociliary activity is a proper sign of nasal mucosal functions, and it is a significant defense mechanism of the human organism. Mucociliary clearance is the pivotal defense mechanism of the nasal respiratory systems epithelium. Harmful particles are caught in this mucus barrier and evacuated from nasal cavity by metacron movement of the cilia [5]. Nasal mucociliary clearance measurements are based on the saccharine transit time (STT) method that described in 1988 by Salah et al. [6]. Inhaled cigarette smoke significantly deteriorates the mucociliary clearance, which is the basic protection mechanism of the upper and the lower respiratory pathways. Cigarette smoke exerts its effects on mucociliary clearance by decreasing the number [7] and the motion $[8,9]$ of the cilia.

Inflammation is a protective response for the persistence of the organism by preventing the damage by microorganisms or toxins to cells, or by eliminating the necrotic and dead tissues that occurred due to damage [10]. Inflammation is related with a series of chronic conditions like cardiovascular disease and cancer. Reducing the inflammation may help for prevention or treatment of these diseases [11]. Cytokines are mediators that comprise many cell types like CD4+T lymphocytes and activated macrophages. Immature CD4+ T cells (TH0) have potential to differentiate into TH1 and TH2 cells, which have ability to secrete different cytokines [12]. Bacterial compounds, immune complexes, toxins, physical damages and various inflammatory events can induce cytokine secretion. Cytokines are polypeptides and most important of them in inflammation are interleukins (IL) and tumor necrosis factor-alpha (TNF- $\alpha$ ).

TNF- $\alpha$ is a strong cytokine that mediates inflammatory and immune reactions [13]. Many cells like activated monocytes, macrophages, and less commonly activated T cells, B cells, mast cells, fibroblasts, keratinocytes, kuppfer cells, smooth muscles, synovial cover cells, and basophils release TNF- $\alpha$. TNF- $\alpha$ is primarily produced by macrophages for inflammation, fever, release of stress hormones and acute phase proteins, chemotaxis and diapedesis of neutrophils, and activation of macrophages [14, 15]. IL-4 is a strong and multifunctional cytokine that is produced by $\mathrm{T}$ lymphocytes, mast cells, and basophils for inducing the growth and differentiation of IgE secreting B-lymphocytes. Smoking is associated with increased serum IL-4 levels and development of allergy-like symptom risks [16].

IL-6 is primarily released from vascular endothelial cells, mononuclear phagocytes, fibroblasts, and activated T lymphocytes [17]. Elevated serum IL-6 levels are associated with many cancer types, primarily prostate, bladder, colon and breast cancer [18]. IL-8 is a member of chemokine family. The source of IL-8 is monocytes, macrophages, fibroblasts, keratinocytes, and endothelium cells. Chemokines affect functions of target cells rather than their dominant growth and have an crucial function in migration of specific cells to the tissue damage and inflammation sites [19]. IL-10 is formed by activated macrophages and TH2 cells. This is mainly an inhibitor cytokine. It particularly inhibits cytokine production [20]. Rodrigues F.M.M. et al. [21] could not determine a change in serum IL-10 levels following 1 month of smoking cessation in their study that included 25 patients in Brazil.

The compounds of cigarette smoke (especially reactive oxidative particles) activate epithelial intracellular signals that yield inflammatory gene activation (IL-8 and TNF- $\alpha$ ) [22]. The release of these inflammatory cytokines increase chronic immune cellular inflammation. The increased interleukin-6 levels are associated with increased systemic inflammation, cardiovascular disease, and cancer progression risks [11]. Previous studies showed that smoking increases the proinflammatory cytokines like TNF- $\alpha$, IL-6, IL- 8 , and decreases the anti-inflammatory cytokines like IL-10 [23, 24].

Assessment of association between inflammatory markers and smoking for explaining the mortality and morbidity due to smoking has gained importance recently [11]. For this reason, we aimed to evaluate the changes both in the systemic inflammation and also in the mucociliary clearance following smoking cessation, and their associations with smoking related characteristics.

\section{Methods \\ Study population}

The ethics boards of Selçuk University Medical School approved this study (2016/10). Informed consent forms concordant with the 1964 Helsinki declaration and its later amendments were received from each participant before the study.

We excluded the participants $<18$ and $>55$ years-of-age; patients with a history of chronic upper and lower respiratory system disease (e.g. chronic obstructive pulmonary disease, asthma, bronchiectasis, chronic bronchitis, concha bullosa, cystic fibrosis, Kartegener syndrome, primary ciliary dyskinesia, septum deviation, turbinate hypertrophy, allergic rhinitis, atrophic rhinitis, chronic sinusitis, chronic otitis media, nasal discharge, nasal polyps);nasal and paranasal operations; patients who had upper and lower respiratory tract infections in the last two months; patients who used medications including flunisolide, phenylephrine, epinephrine, lidocaine, atropine, antihistamines, and other drugs that may affect the mucus structure and ciliary activity in the last two weeks; other systemic disease (e.g. diabetes mellitus, rheumatoid arthritis, systemic lupus erythematosus); alcohol abuse and pregnant or nursing mothers. 
A total of 30 participants admitted to Konya Training and Research Hospital, University of Health Sciences Smoking Cessation Department were recruited, and 27 of them completed the study. Three participants had high urine cotinine levels (>500 ng/ml was regarded as exposure to smoke [25] at the end of second month and excluded from the study. Participants were informed about the study and they completed a form including sociodemographic characteristics and smoking habits. Participants that enrolled to smoking cessation program used a combination therapy including counselling and bupropion and/or varenicline for a 2-month period. After then, they were asked whether they continue or quit smoking, which confirmed by urine cotinine analyses. TNF- $\alpha$, IL-4, IL-6, IL-8, IL-10, and STT were measured at enrollment and $2^{\text {nd }}$ month follow-up visits.

\section{Laboratory Analysis}

Blood samples taken at the beginning and end of the study were taken immediately into serum separation tubes. Sera were obtained by centrifugation at $1500 \times \mathrm{g}$ for $10 \mathrm{~min}$. The samples were immediately put in the freezer at $-80^{\circ} \mathrm{C}$. The same process was applied to all the specimens . At the end of the study urine samples were frozen at $-80^{\circ} \mathrm{C}$. When the study was completed, cotinine and TNF- $\alpha$, IL-4, IL- 6 , IL- 8 and IL- 10 were studied in urine samples and blood samples, respectively.

The concentrations of interleukin IL-4, IL-6, IL-8, IL-10 and TNF- $\alpha$, in human sera were determined using solid phase sandwich ELISA (Diaclone SAS, Besancon Cedex, France). The assays were performed as described by the manufacturer. The reported detection limits were $0,70 \mathrm{pg} / \mathrm{ml}$ for IL-4, $2 \mathrm{pg} / \mathrm{ml}$ for IL-6, $29 \mathrm{pg} / \mathrm{ml}$ for IL-8, 4,90 pg/ml for IL-10 and $8 \mathrm{pg} / \mathrm{ml} \mathrm{TNF} \alpha$. The standard curve fitted between 0 and $35 \mathrm{pg} / \mathrm{ml}$ for IL-4, 0 and $200 \mathrm{pg} / \mathrm{ml}$ for IL-6, between 0 and $2000 \mathrm{pg} / \mathrm{ml}$ for IL-8, between 0 and $400 \mathrm{pg} / \mathrm{ml}$ for IL-10 and 0 and $800 \mathrm{pg} / \mathrm{ml}$ for TNF- $\alpha$,. The Cotinine (DRG® Cotinine (Urine) (EIA-1377), USA) microplate ELISA was used for the screening for the presence of cotinine in human urine.

\section{Carbon monoxide (CO) measurement}

$\mathrm{CO}$ measurements were done by the piCO Smoker lyzer (0-100 ppm) (Bedfont Scientific, Harrietsham, UK) in the expiratory airflow during the confirmation and exclusion of the study participants' smoking statuses [26].

\section{Smoking characteristics}

The Turkish version of the questionnaire, which was proposed by Prochaska et al. [27] and used in the US for the evaluation, ranking, and classification of the stages of change in cessation of smoking and its characteristics, was used for the study participants while the Fagerstrom Test for Nicotine Dependence (FTND) questions were used for the scoring and classification of dependence [28].

\section{Saccharin transit time test}

First, patients were examined by an otolaryngology specialist. Then, saccharine test was performed by the same otolaryngology specialist for participants who were eligible for the study. All saccharin tests were performed by the same otorhinolaryngologist blinded to the study under the same climatic conditions (room temperature $23^{\circ} \mathrm{C}$, relative humidity $60 \%$ ) and the participants were rested for 30 minutes before the saccharin test. The tests were done while the participants was sitting and holding his head upright. For the test, patients cleaned the secretions in their noses. Then, $1 / 4$ of a saccharine tablet ( $1 / 4$ of a hermesetas $12.5 \mathrm{mg}$ ) was placed just behind the front end of lower concha by a port cotton in nasal cavity. Timer was started, and patient was told to sit stable, and not to sneeze, perform eating-drinking movements, drop head, or sniff. At every 30 seconds, he/she was asked if there was a feeling of taste. The time that participantsfelt taste was recorded as mucociliary clearance time.

\section{Statistical analysis}

Statistical analyses were performed with SPSS (SPSS Inc., Chicago, IL, USA,) version 21.0 software. Numbers, percentages, means, and standard deviation were used for data presentation. Paired t-test were used for data analyses between the groups of the study. A p value $<0.05$ was considered statistically significant.

\section{Results}

A total of 27 participants were included in the final data analyses. The mean age was 44.6 \pm 8.50 years (min-max: 29-55 years; median: 47 years), and the mean BMI was $27.10 \pm 3.70 \mathrm{~kg} / \mathrm{m}^{2}$ (min-max: $18.30-32.50 \mathrm{~kg} / \mathrm{m}^{2}$; median: $27.70 \mathrm{~kg} / \mathrm{m}^{2}$ ). Female to male ratio was $22.20 \%$ (n=6) to $77.80 \%$ $(\mathrm{n}=21)$, respectively, and all were living in urban areas. The distribution of education levels was as $25.92 \%(\mathrm{n}=7)$ elementary school, $11.11 \%(\mathrm{n}=3)$ secondary school, $44.44 \%(\mathrm{n}=12)$ high school, and $18.51 \%(\mathrm{n}=5)$ vocational college or university. The smoking characteristics of participants at enrollment are presented in Table 1.

Mean CO level of patients was $4.80 \pm 2.40 \mathrm{ppm}$, and $2^{\text {nd }}$ month urine cotinine level was $168.4 \pm 91.50 \mathrm{ng} / \mathrm{ml}$ (min-max: 40.20-403.20 ng/ml; median: $158.90 \mathrm{ng} / \mathrm{ml}$ ). STT, TNF- $\alpha$, IL-4, IL-6, IL-8, and IL-10 levels of participants at enrollment and after quitting are presented in Table 2.

Comparison of STT, TNF- $\alpha$, IL-4, IL-6, IL-8, and IL-10 levels of participants according to tobacco use by pack-years are presented in Table 3.

Comparison of STT, TNF- $\alpha$, IL-4, IL-6, IL-8, and IL-10 levels of participants according to tobacco use by yearsare presented in Table 4 . 
Table 1. The smoking characteristics of patients at enrollment.

\begin{tabular}{lccc}
\hline $\begin{array}{l}\text { Smoking characteristics } \\
(\mathbf{n}=27)\end{array}$ & Mean \pm SD & Median & Min-Max \\
\hline Onset of smoking age & $17.14 \pm 4.18$ & 15 & $7-26$ \\
Cigarettes/day & $24.29 \pm 9.27$ & 20 & $10-40$ \\
Years of smoking & $27.29 \pm 9.47$ & 30 & $10-43$ \\
Pack. Years & $29.75 \pm 13.41$ & 27 & $10-65$ \\
FTND & $6.40 \pm 2.22$ & 7 & $2-10$ \\
\hline
\end{tabular}

Table 2. Comparison of STT, TNF- $\alpha$, IL-4, IL-6, IL-8, and IL-10 levels of patients at enrollment and after quitting.

\begin{tabular}{|c|c|c|c|c|}
\hline & Enrollment & $2^{\text {nd }}$ month & $t / Z$ & $p$ \\
\hline STT $(\min )^{1}$ & $7.92 \pm 2.42$ & $5.21 \pm 2.74$ & $5.172 *$ & $<0.001$ \\
\hline TNF alfa ${ }^{2}$ & $25.00(18.14-49.26)$ & $22.55(15.69-31.13)$ & $-2.103 * *$ & 0.035 \\
\hline IL-4 (pg/ml) ${ }^{1}$ & $0.63 \pm 0.12$ & $0.67 \pm 1.11$ & $-2.178 *$ & 0.039 \\
\hline IL-6 (pg/ml) ${ }^{1}$ & $6.53 \pm 0.87$ & $6.81 \pm 0.81$ & $-1.556^{*}$ & 0.132 \\
\hline IL-8 $(\mathrm{pg} / \mathrm{ml})^{2}$ & $28.24(17.87-64.16)$ & $22.63(18.06-72.26)$ & $-3.099 * *$ & 0.002 \\
\hline IL-10 $(\mathrm{pg} / \mathrm{ml})^{2}$ & $7.27(5.82-15.21)$ & $7.50(5.80-17.27)$ & $-4.443 * *$ & 0.657 \\
\hline
\end{tabular}

*Paired T test, **Wilcoxon test

Table 3. Comparison of STT, TNF- $\alpha$, IL-4, IL-6, IL-8, and IL-10 levels of patients according to tobacco use by pack-years.

\begin{tabular}{|c|c|c|c|c|c|c|c|c|}
\hline \multirow[b]{3}{*}{ STT $(\min )^{1}$} & \multicolumn{4}{|c|}{$\begin{array}{c}\leq 20 \text { pack. years } \\
(n=8)\end{array}$} & \multicolumn{4}{|c|}{$\begin{array}{c}\geq 21 \text { pack. years } \\
(\mathrm{n}=19)\end{array}$} \\
\hline & Enrollment & $2^{\text {nd }}$ month & $t / Z$ & $p$ & Enrollment & $2^{\text {nd }}$ month & $t$ & $p$ \\
\hline & $8.67 \pm 2.30$ & $5.24 \pm 3.48$ & $2.902 *$ & 0.023 & $7.60 \pm 2.46$ & $5.20 \pm 2.47$ & 4.277 & $<0.001$ \\
\hline TNF alfa ${ }^{2}$ & $28.89 \pm 8.77$ & $24.38 \pm 3.11$ & $1.921 * *$ & 0.096 & $24.11 \pm 4.40$ & $23.09 \pm 4.05$ & 1.125 & 0.275 \\
\hline IL-4 (pg/ml) $)^{1}$ & $0.66 \pm 0.14$ & $0.73 \pm 0.13$ & $-2.644 *$ & 0.033 & $0.62 \pm 0.11$ & $0.65 \pm 0.09$ & -1.200 & 0.246 \\
\hline IL-6 $(\mathrm{pg} / \mathrm{ml})^{1}$ & $6.33 \pm 0.56$ & $6.77 \pm 1.02$ & $-0.946 *$ & 0.376 & $6.62 \pm 0.97$ & $6.83 \pm 0.74$ & -1.223 & 0.237 \\
\hline IL-8 $(\mathrm{pg} / \mathrm{ml})^{2}$ & $31.31 \pm 9.62$ & $29.61 \pm 17.58$ & $0.538 * *$ & 0.607 & $30.98 \pm 11.87$ & $22.76 \pm 3.42$ & 2.875 & 0.010 \\
\hline IL-10 $(\mathrm{pg} / \mathrm{ml})^{2}$ & $7.76 \pm 1.73$ & $7.52 \pm 0.36$ & $0.361 * *$ & 0.728 & $8.16 \pm 2.23$ & $7.99 \pm 2.45$ & 0.726 & 0.477 \\
\hline
\end{tabular}

*Paired T test, **Wilcoxon test

Table 4. Comparison of STT, TNF- $\alpha$, IL-4, IL-6, IL-8, and IL-10 levels of patients according to tobacco use by years

\begin{tabular}{|c|c|c|c|c|c|c|c|c|}
\hline & & $\begin{array}{r}\leq 20 \text { year } \\
(n=9)\end{array}$ & & & & $\begin{array}{c}\geq 21 \text { years } \\
(n=18)\end{array}$ & & \\
\hline & Enrollment & $2^{\text {nd }}$ month & $t / Z$ & $p$ & Enrollment & $2^{\text {nd }}$ month & $t$ & $p$ \\
\hline STT $(\min )^{1}$ & $8.59 \pm 1.73$ & $5.38 \pm 2.92$ & $2.722 *$ & 0.026 & $7.58 \pm 2.68$ & $5.13 \pm 2.73$ & 4.562 & $<0.001$ \\
\hline TNF alfa ${ }^{2}$ & $27.92 \pm 3.01$ & $24.53 \pm 2.17$ & $3.589 * *$ & 0.007 & $24.33 \pm 7.14$ & $22.94 \pm 4.34$ & 1.017 & 0.323 \\
\hline IL-4 (pg/ml $)^{1}$ & $0.59 \pm 0.07$ & $0.68 \pm 0.07$ & $-4.580 *$ & 0.002 & $0.65 \pm 0.14$ & $0.67 \pm 0.12$ & -0.801 & 0.434 \\
\hline IL-6 $(\mathrm{pg} / \mathrm{ml})^{1}$ & $6.37 \pm 0.76$ & $6.43 \pm 0.49$ & $-0.168 *$ & 0.871 & $6.61 \pm 0.93$ & $7.00 \pm 0.88$ & -1.855 & 0.081 \\
\hline IL-8 $(\mathrm{pg} / \mathrm{ml})^{2}$ & $31.75 \pm 10.53$ & $23.16 \pm 3.76$ & $2.238 * *$ & 0.056 & $30.74 \pm 11.62$ & $25.60 \pm 12.10$ & 1.811 & 0.088 \\
\hline IL-10 $(\mathrm{pg} / \mathrm{ml})^{2}$ & $7.66 \pm 1.66$ & $7.37 \pm 0.31$ & $0.534 * *$ & 0.608 & $8.22 \pm 2.27$ & $8.09 \pm 2.50$ & 0.524 & 0.607 \\
\hline
\end{tabular}

*Paired T test, **Wilcoxon test

\section{Discussion}

Smoking is associated with a wide spectrum of variation in systemic immune and inflammation marker levels between older, long-term smokers. As a result of smoking cessation, the level of systemic immune and inflammation of individuals decreases over time to the level of people who never smoked [29]. Previous studies showed that tobacco use deteriorates mucociliary activity [30, 31]. Ramos et al.[ 32] conducted a study with 33 participants in Brazil, and found that saccharin transit time shortens after 15 days from cessation. Another study from Brazil with 33 patients was conducted by Utiyama et al. [33] and authors reported that quitting provides rapid improvement in nasal mucociliary clearance independently from mucus characteristics and inflammation. In the present study that saccharin transit times shortened significantly 2 months after cessation.

The number of studies that evaluated changes in systemic inflammation characteristics following smoking cessation is very limited. Long-time smoking induces airway inflammation that characterized by neutrophil, macrophage, and activated T lymphocyte infiltration, and increases the TNF- $\alpha$, IL-6 and IL-8 concentrations [34-37]. Tanni et al. [38] found that serum TNF- $\alpha$ levels were higher in smokers than non-smokers. Natural killer cells generate significantly less IFN-y and TNF- $\alpha$ on activation in smokers when compared to non-smokers [39].Cigarette smoke components, especially ROS, activate epithelial cell intracellular signaling cascades as a consequence lead to inflammatory gene activation $[e . g$., IL-8 or IL-8 and TNF- $\alpha]$ [40, 41]. 
Diez et al.[42] conducted a study in Spain with 51 patients, and found that TNF- $\alpha$ levels were higher in smokers than non-smokers. Braber et al. [43] found in their study that the proinflammatory cytokines IL-1, IL-12 and TNF- $\alpha$ levels were increased in broncho-alveolar lavage of rats after an exposure to cigarette smoke for 20 weeks. In the same study, IL-1a and TNF- $\alpha$ levels were found to be decreased to basal levels at 8 weeks after the elimination of the smoke. Rodrigues et al. [21] conducted a study in Brazil with 25 patients, and found that TNF- $\alpha$ levels decreased significantly in patients who quit smoking for 30 days when compared to active smokers. In our study, we found that serum TNF- $\alpha$ levels were decreased significantly at 2 months after quitting when compared with the basal levels.

Merghani et al. [44] evaluated the second-hand smoke exposure of Sudanese children at home, and found that these children had elevated serum levels of IL-4 and TNF- $\alpha$. Kim. et al. [45] conducted a study on 25 participants in USA, and found that smokers had higher levels of IL-4 when compared to non-smokers and patients with chronic obstructive pulmonary disease. In the present study serum IL-4 levels were significantly increased at 2 months after quitting.

Mendal et al. [46] reported that serum IL-6 levels were increased in smokers. However, Rodrigues et al. [21] found that quitters and active smokers had similar IL-6, IL-8, and IL-10 levels, and they mentioned that 30 days was a relatively short period for quitting. Similarly, Van Keulen et al. [47] found in their study in Brazil that serum levels of TNF- $\alpha$, IL-1, IL-6, IL-8, IL-10 and IL-12 were similar at $4^{\text {th }}$ month of quitting when compared to basal levels. In the present study, serum IL-6 and IL-10 levels did not change significantly at $2^{\text {nd }}$ month of quitting, when compared to basal levels. This may be related with the small sample size and relatively short duration of 2 months of quitting.

Holvorsen et al. [48] conducted a study in Norway with 41 patients, and found that IL- 8 gene expression was decreased, and IL- 6 and TNF- $\alpha$ concentrations did not changed after 1 year of follow-up. In another study with 25 patients in Holland, Willemse et al. [49] found that IL-8 levels in sputum were significantly decreased at 1 year after quitting. In our study, serum IL-8 levels were significantly decreased after 2 months from quitting.

\section{Conclusion}

Nasal mucociliary response and systemic inflammatory response, particularly plasma TNF- $\alpha$ and IL-8 levels improve significantly at 2 months after quitting. We think that, further studies with larger sample size and longer follow-up will provide more detailed data about the improvements in systemic inflammation.

\section{Conflict of interest: None}

Financial disclosure: The study was funded by the research fund of Konya Training and Research Hospital.

\section{References}

1. The Word Bank. Tobacco Control Progam. Access. April 14, 2018. http://www.worldbank.org/en/topic/health/brief/tobacco

2. Patel I, Seemungal T, Wilks M, et al. Relationship between bacterial colonisation and the frequency, character, and severity of COPD exacerbations. Thorax. 2002;57(9):759-64. doi: http://dx.doi.org/10.1136/thorax.57.9.759

3. Reichert J, Araújo AJd, Gonçalves CMC, et al. Smoking cessation guidelines-2008. J Bras Pneumol. 2008;34(10):845-80. doi: http://dx.doi.org/10.1590/S1806$\underline{37132008001000014}$

4. Lao XQ, Jiang CQ, Zhang WS, et al. Smoking, smoking cessation and inflammatory markers in older Chinese men: The Guangzhou Biobank Cohort Study. Atherosclerosis. 2009;203(1):304-10. doi: https://doi.org/10.1016/j.atherosclerosis.2008.06.028

5. Deitmer T. Physiology and pathology of the mucociliary system. Special regards to mucociliary transport in malignant lesions of the human larynx. Adv Otorhinolaryngol. 1989:43:105-36. doi: https://doi.org/10.1159/000417244

6. Salah B, Xuan AD, Fouilladieu J, et al. Nasal mucociliary transport in healthy subjects is slower when breathing dry air. Eur Respir J. 1988;1(9):852-5. PMID: https://www.ncbi.nlm.nih.gov/pubmed/3229484

7. Özlü T, Çay M, Akbulut A, et al. The facilitating effect of cigarette smoke on the colonization of instilled bacteria into the tracheal lumen in rats and the improving influence of supplementary vitamin E on this process. Respirology. 1999;4(3):245-8. doi: https://doi.org/10.1046/j.1440-1843.1999.00182.x

8. Agius AM, Wake M, Pahor AL, et al. Smoking and middle ear ciliary beat frequency in otitis media with effusion. Acta oto-laryngologica. 1995;115(1):44-9. doi: https://doi.org/10.3109/00016489509133345

9. Cohen NA, Zhang S, Sharp DB, et al. Cigarette smoke condensate inhibits transepithelial chloride transport and ciliary beat frequency. The Laryngoscope. 2009;119(11):2269-74. doi: https://doi.org/10.1002/lary.20223

10. Ferrero-Miliani L, Nielsen O, Andersen P, et al. Chronic inflammation: importance of NOD2 and NALP3 in interleukin-1 $\beta$ generation. Clin Exp Immunol. 2007;147(2):227-35. doi: https://doi.org/10.1111/j.1365-2249.2006.03261.x

11. Aldaham S, Foote JA, Chow H-HS, et al. Smoking status effect on inflammatory markers in a randomized trial of current and former heavy smokers. Int J Inflam. 2015;2015:439396. doi: http://dx.doi.org/10.1155/2015/439396

12. Park JE, Barbul A. Understanding the role of immune regulation in wound healing. Am J of Surg. 2004;187(5): 11-6. doi: https://doi.org/10.1016/S00029610(03)00296-4

13. Strieter RM, Kunkel SL, Bone RC. Role of tumor necrosis factor-[alpha] in disease states and inflammation. Crit Care Med.1993;21(10):447. PMID: https://www.ncbi.nlm.nih.gov/pubmed/8403983

14. Beutler B, Cerami A. The biology of cachectin/TNF--a primary mediator of the host response. Ann Rev Immunol. 1989;7(1):625-55. doi: https://doi.org/10.1146/annurev.iy.07.040189.003205

15. Newman I, Wilkinson P. Chemotactic activity of lymphotoxin and tumour necrosis factor alpha for human neutrophils. Immunology. 1989;66(2):318. PMID: https://www.ncbi.nlm.nih.gov/pubmed/2925230 
16. Byron K, Varigos G, Wootton A. Il-4 production is increased in cigarette smokers. Clin Exp Immunol. 1994;95(2):333-6. doi: https://doi.org/10.1111/j.13652249.1994.tb06533.x

17. Landskron G, De la Fuente M, Thuwajit P, et al. Chronic inflammation and cytokines in the tumor microenvironment. J Immunol Res. 2014;2014. doi: http://dx.doi.org/10.1155/2014/149185

18. Neurath MF, Finotto S. IL-6 signaling in autoimmunity, chronic inflammation and inflammation-associated cancer. Cytokine Growth Factor Rev. 2011;22(2):839. doi: https://doi.org/10.1016/j.cytogfr.2011.02.003

19. Stites DP TA, Parslow TG. Medical Immunology. 1997. https://trove.nla.gov.au/version/45738641

20. Mayer, G. (2010) Cytokines and immunoregulation, Immunology - Chapter 12: 7th edition, The Board of Trustees of the University of South Carolina. Online book. http://pathmicro.med.sc.edu/bowers/imm-reg-ver2.htm.

21. Rodrigues FM, Ramos D, Xavier RF, et al. Nasal and systemic inflammatory profile after short term smoking cessation. Respir Med. 2014;108(7):999-1006. doi: https://doi.org/10.1016/j.rmed.2014.04.020

22. Lee J, Taneja V, Vassallo R. Cigarette smoking and inflammation: cellular and molecular mechanisms. J Dent Res. 2012;91(2):142-9. doi: https://doi.org/10.1177/0022034511421200

23. Diez-Pina JM, Fernandez-Aceñero MJ, Llorente-Alonso MJ, et al. Tumor necrosis factor alpha as a marker of systemic and local inflammation in "healthy" smokers. Int J Gen Med. 2009; 2: 9-14. PMID: https://www.ncbi.nlm.nih.gov/pubmed/20360881. 2009;2:9

24. Arnson Y, Shoenfeld Y, Amital H. Effects of tobacco smoke on immunity, inflammation and autoimmunity. J Autoimmun. 2010;34(3):258-65. doi: https://doi.org/10.1016/j.jaut.2009.12.003

25. Yu H-J, Lim S, Kim M-K, et al. Urine cotinine level with smoking history predicts a risk of coronary artery calcification. Environ Toxicol Pharmacol. 2018;59:146-51. doi: https://doi.org/10.1016/j.etap.2018.03.015

26. Al-Sheyab N, Kheirallah KA, Mangnall LJT, et al. Agreement between exhaled breath carbon monoxide threshold levels and self-reported cigarette smoking in a sample of male adolescents in Jordan. Int J Environ Res Public Health. 2015;12(1):841-54. doi: https://doi.org/10.3390/ijerph120100841

27. Prochaska JO, Goldstein MG. Process of smoking cessation. Implications for clinicians. Clin Chest Med. 1991;12(4):727-35. PMID: https://www.ncbi.nlm.nih.gov/pubmed/1747990

28. Fagerstrom KO, Heatherton TF, Kozlowski LT. Nicotine addiction and its assessment. Ear Nose Throat J. 1990;69(11):763-5. PMID: https://www.ncbi.nlm.nih.gov/pubmed/2276350

29. Shiels MS, Katki HA, Freedman ND, et al. Cigarette smoking and variations in systemic immune and inflammation markers. J Natl Cancer Inst. 2014;106(11). doi: https://doi.org/10.1093/jnci/dju294

30. Xavier RF, Ramos D, Ito JT, et al. Effects of cigarette smoking intensity on the mucociliary clearance of active smokers. Respiration. 2013;86(6):479-85. doi: https://doi.org/10.1159/000348398

31. Yadav J, Kaushik G, K Ranga R. Passive smoking affects nasal mucociliary clearance. J Indian Acad Clin Med. 2014;15 (2):96-9.

32. Ramos EM, De Toledo AC, Xavier RF, et al. Reversibility of impaired nasal mucociliary clearance in smokers following a smoking cessation programme. Respirology. 2011;16(5):849-55. doi: https://doi.org/10.1111/j.1440-1843.2011.01985.x

33. Utiyama DMO, Yoshida CT, Goto DM, et al. The effects of smoking and smoking cessation on nasal mucociliary clearance, mucus properties and inflammation. Clinics. 2016;71(6):344-50. doi: http://dx.doi.org/10.6061/clinics/2016(06)10

34. Quint JK, Wedzicha JA. The neutrophil in chronic obstructive pulmonary disease. J Allergy Clin Immunol. 2007;119(5):1065-71. doi: https://doi.org/10.1016/j.jaci.2006.12.640

35. Gamble E, Grootendorst DC, Hattotuwa K, et al. Airway mucosal inflammation in COPD is similar in smokers and ex-smokers: a pooled analysis. Eur Respir J. 2007;30(3):467-71. doi: https://doi.org/10.1183/09031936.00013006

36. Baraldo S, Turato G, Badin C, et al. Neutrophilic infiltration within the airway smooth muscle in patients with COPD. Thorax. 2004;59(4):308-12. doi: http://dx.doi.org/10.1136/thx.2003.012146

37. Battaglia S, Mauad T, van Schadewijk AM, et al. Differential distribution of inflammatory cells in large and small airways in smokers. J Clin Pathol. 2007;60(8):907-11. doi: http://dx.doi.org/10.1136/jcp.2006.037002

38. Tanni SE, Pelegrino NR, Angeleli AY, et al. Smoking status and tumor necrosis factor-alpha mediated systemic inflammation in COPD patients. J Inflamm (Lond). 2010;7(1):29. doi: https://doi.org/10.1186/1476-9255-7-29

39. Mian MF, Lauzon NM, Stämpfli MR, et al. Impairment of human NK cell cytotoxic activity and cytokine release by cigarette smoke. J Leukoc Biol. 2008;83(3):774-84. doi: https://doi.org/10.1189/jlb.0707481

40. Churg A, Dai J, Tai H, et al. Tumor necrosis factor- $\alpha$ is central to acute cigarette smoke-induced inflammation and connective tissue breakdown. Am J Respir Crit Care Med. 2002;166(6):849-54. doi: https://doi.org/10.1164/rccm.200202-0970C

41. Chung KF. Inflammatory mediators in chronic obstructive pulmonary disease. Curr Drug Targets Inflamm Allergy. 2005;4(6):619-25. doi: https://doi.org/10.2174/156801005774912806

42. Díez PJ, Fernández AM, Llorente AM, et al. Tumor necrosis factor as an early marker of inflammation in healthy smokers. Med Clin (Barc). doi: https://doi.org/10.1016/j.medcli.2011.11.032 2012;139(2):47-53.

43. Braber S, Henricks PA, Nijkamp FP, et al. Inflammatory changes in the airways of mice caused by cigarette smoke exposure are only partially reversed after smoking cessation. Respir Res. 2010;11(1):99. doi: https://doi.org/10.1186/1465-9921-11-99

44. Merghani TH, Saeed A, Alawad A. Changes in plasma IL4, TNFa and CRP in response to regular passive smoking at home among healthy school children in Khartoum, Sudan. Afr Health Sci. 2012;12(1):41-7. PMID: https://www.ncbi.nlm.nih.gov/pubmed/23066418

45. Kim V, Cornwell WD, Oros M, et al. Plasma Chemokine signature correlates with lung goblet cell hyperplasia in smokers with and without chronic obstructive pulmonary disease. BMC Pulm Med. 2015;15(1):111. doi: https://doi.org/10.1186/s12890-015-0103-2

46. Mendall M, Patel P, Asante M, et al. Relation of serum cytokine concentrations to cardiovascular risk factors and coronary heart disease. Heart. 1997;78(3):2737. doi: http://dx.doi.org/10.1136/hrt.78.3.273

47. Van Keulen H, Gomes A, Toffolo M, et al. Serum levels of nitric oxide and cytokines in smokers at the beginning and after 4months of treatment for smoking cessation. Int J Cardiol. 2017;230:327-31. doi: https://doi.org/10.1016/j.ijcard.2016.12.111

48. Halvorsen B, Sagen LE, Ueland T, et al. Effect of smoking cessation on markers of inflammation and endothelial cell activation among individuals with high risk for cardiovascular disease. Scand J Clin Lab Invest. 2007;67(6):604-11. doi: https://doi.org/10.1080/00365510701283878

49. Willemse BW, ten Hacken NH, Rutgers B, et al. Effect of 1-year smoking cessation on airway inflammation in COPD and asymptomatic smokers. Eur Respir J. 2005;26(5):835-45. doi: https://doi.org/10.1183/09031936.05.00108904 